\title{
THE EFFECTS OF COVID-19 PANDEMIC TOWARD LEARNING FROM HOME PROCESS IN JUNIOR HIGH SCHOOL IN AMBON CITY: AN EXPLORATION STUDY
}

\author{
Jotty Sartje Haumahu \\ Ambon City Education Office, Maluku \\ e-mail: jottyhau@gmail.com
}

\begin{abstract}
The purpose of this study was to identify and obtain information on the constraints of the online teaching and learning process at home as a result of the Covid-19 pandemic. The research use the exploratory case study method and the research approach utilised the qualitative case study method which was applied to obtain information on the constraints and consequences of the Covid-19 pandemic on teaching and learning activities in junior high school. In this study, respondents were 3 teachers and 3 parents at the Kusu-kusu Sereh Christian Middle School in Ambon. Semi-structured interviews were conducted and a list of questions compiled for interviews was developed based on related literature. The results of this study are that there are several obstacles experienced by students, teachers and parents in teaching and learning activities both online and offline. Obstacles in the online learning process are mainly the lacking technology mastery, the additional cost of internet quota, and lastly the reduced communication and socialization between students, teachers and parents. Obstacles in offline learning are the distance the teacher travels to when visiting the student's residence which is quite far away and the additional work for the teacher in arranging the schedule for student home visits. The same constraints faced in online and offline learning are the existence of additional work for parents in accompanying children to study, and unlimited working hours for teachers because they have to communicate and coordinate with parents, other teachers, and school principals.
\end{abstract}

Key words: Teaching learning process, COVID-19 Pandemic, Exploration Study

\section{Introduction}

The Covid-19 pandemic is the first and most crucial health crisis in the world today. Many countries decide to close schools, colleges, and universities. The 2019 corona virus disease (Covid-19) outbreak which has hit 215 countries in the world, presents its own challenges for educational institutions, especially junior high schools (SMP). More than 1.5 billion children and adults worldwide are out of school and university due to restrictions placed on the spread of the coronavirus. According to UNESCO more than 1.5 billion children and adults worldwide are out of school and university due to restrictions placed on the spread of the coronavirus.

The number of children, young people and adults who are not in school because of COVID-19 is increasing. Governments around the world have closed educational institutions in a bid to curb the global pandemic," said the international organization. More than 160 countries have taken action across their territories, affecting more than $87 \%$ of the global student population. Other countries have implemented closings of local schools and educational institutions.

The crisis really came suddenly, governments anywhere in the world, including Indonesia, had to take the bitter decision to close schools in order to massively reduce people's contact. However on the other hand, the government feels the need to save workers' lives and still has to open schools in the context of workers' safety in maintaining economic sustainability. There are two impacts on the sustainability of education caused by the Covid-19 pandemic. The first is the short-term impact felt by many families in Indonesia, both in cities and in villages. In Indonesia, many families find it unusual to learn from home. Home schooling for Indonesian families is a big surprise especially for the productivity of parents who are usually busy with work outside 
the home. There is also a psychological problem with children who are accustomed to face-to-face learning with their teachers. All elements of education in social life are "exposed" to illness due to Covid-19.

Currently in Indonesia, several campuses and schools have begun to implement policies for remote teaching and learning activities or online lectures. Everyone then took distance to break the chain of transmission of COVID-19. Places of worship are now getting quiet, mass agendas are being eliminated, and also SARS-CoV-2 is also why the term "Work from Home" (WFH) trending. It is not enough, schools and colleges have also been established. As if all of that are not enough, the corona virus also has a serious impact on the education sector, both in Indonesia and globally.

The similarity of the situation between Indonesia and other countries in the world must be addressed carefully. Even under normal circumstances, there are many imbalances that occur between regions. The Ministry of Education, under the leadership of Minister Nadiem Makarim, echoes the spirit of increasing productivity for students to raise job opportunities when they graduate from a school. However, with the sudden arrival of the Covid-19 outbreak, the Indonesian education world needs to follow the path if it can help school conditions in an emergency. Schools need to force themselves to use online media.

However, the use of technology is not without problems, there are many variances of problems that hinder the effectiveness of learning with online methods, including:

1). Students and teachers limited capability in technology. The condition of teachers in Indonesia does not fully understand the use of technology, this can be seen from teachers who were born before the 1980s. Information technology constraints limit their use of online media. Likewise with students whose conditions are almost the same as teachers who have difficulties in using technology. 2). Inadequate Facilities and Infrastructure. Tech support devices are obviously expensive. Many teachers in parts of Indonesia are still in dire economic conditions. The welfare of both teachers and students limits them with all their limitations in enjoying the information technology facilities and infrastructure that were very much needed by the Covid-19 disaster. 3). Limited Internet access. The internet network is still uneven in all corners of the country. Not all educational institutions, both primary and secondary schools, can enjoy the internet. Even if there is an internet network the condition is still unable to cover online media. 4). Poor budget preparation. Costs are also an obstacle because aspects of the welfare of teachers and students are still far from expectations. When they use internet quotas to meet their online media needs, it is clear that they cannot pay for it continuously. There is a dilemma in the use of online media, when the minister of education encourages productivity to move forward, but on the other hand the financial skills and abilities of teachers and students have not moved in the same direction. The state has not yet been fully present in facilitating the said financial needs.

Not all schools are able to carry out Learning from Home activities online because of various obstacles, such as the geographical conditions where students live which are not reached by the internet network, the economic conditions of parents who are middle and lower, so students do not have an Android cellphone. Even if there is a cellphone, there is no cost to buy a data package for online learning. Thus in addition to online learning, the learning process is also carried out offline and home visits. This results in additional work that is quite heavy, especially for teachers who have students with the conditions mentioned above. Like it or not, the learning process must continue to be carried out even with minimal conditions. What is most needed now is the commitment of every element of education to continue to provide the best for students during this Covid-19 pandemic.

SMP Kristen Kusu-Kusu Sereh Ambon is one of the schools located in Urimessing village, Ambon city. SMP Kristen Kusu-Kusu Sereh Ambon is under the auspices of the Maluku Protestant Church Christian Education Development Foundation (YPPK GPM). 
The distribution of residences for students of SMP Kristen Kusu-Kusu Sereh in Ambon is in villages like Talaga Raja, Kusu-Kusu Sereh, Tuni, and Mahia. Tuni and Mahia vilage in several locations do not have internet network access. Most of the parents' jobs are farmers, fishermen, taxibike, and construction workers. There are a small number of parents of students who are ASN (State Civil Service) and TNI-Polri (Soldiers and Police).

Based on existing data at SMP Kristen Kusu-Kusu Sereh Ambon, out of 127 students there are only 11 students who have Android phones. Of the 127 parents of students, only 55 have Android phones, the rest have ordinary cellphones that can only run SMS and telephone functions.

Basicly, the condition of students and parents at SMP Kristen Kusu-Kusu Sereh, the learning carried out during the Covid-19 pandemic uses a home visit approach carried out by the teacher to provide learning material and assignments carried out by students. This visit is scheduled regularly so that Monday-Friday in the current week, students get lesson material from the teacher.

The purpose of this study was to obtain information about the impacts and constraints of the Covid-19 pandemic on teaching and learning activities at the SMP Kristen Kusu-Kusu Sereh in Ambon using qualitative exploratory methods.

\section{Methodology}

The research used an exploratory case study method and the research approach used a qualitative case study method which was used to obtain information on the constraints and consequences of the Covid-19 pandemic on teaching and learning activities at SMP Kristen Kusu-Kusu Sereh, Ambon. The sample size is based on achieving depth and richness of description, not sample size. According to Guetterman (2015), sample size is not a matter of representative opinion and views, but rather a matter of information wealth. In this study, respondents were 8 teachers and 8 parents of students. Semistructured interviews were conducted and a list of questions compiled for interviews was developed based on related literature. Respondents for this study were the teachers and parents of students at 4 junior high schools which are the researcher's target schools in Ambon City.

Table 1. Respondents' Profile

\begin{tabular}{|c|c|c|c|l|}
\hline $\begin{array}{c}\text { Initial } \\
\text { Respondent }\end{array}$ & Sex & Age & Status & \multicolumn{1}{|c|}{ Education } \\
\hline R1 & Male & 51 & Married & Bachelor \\
\hline R2 & Female & 56 & Married & Bachelor \\
\hline R3 & Female & 53 & Married & Bachelor \\
\hline R4 & Female & 48 & Married & High School \\
\hline R5 & Male & 44 & Married & High School \\
\hline R6 & Female & 56 & Married & High School \\
\hline
\end{tabular}

The primary collection method is by means of semi-structured interviews, while secondary data is collected from published data such as journal articles and books. This study is limited to a sample size of 6 respondents who live in Ambon City. This research is an exploratory case study and the sample was selected using purposive sampling method. In qualitative research, purposive sampling technique is a method used to achieve certain research objectives. There is no limit to the number of respondents to make a purposive sample, as long as the desired information can be obtained and generated (Bernard, 2002). To conduct case study research, Creswell (2013) provides observations and a number of sample size recommendations, which range from no more than four to five cases. 


\section{Result and Discussion}

\section{a. Result}

The purpose of this study was to obtain information about the impact of the Covid19 epidemic on learning activities at the SMP Kristen Kusu-Kusu Sereh in Ambon, which carried out Learning from Home (BDR) activities with Home Visit strategy.

A respondent (R1) said that "Teachers are forced to go to students' homes to bring modules and explain the material because most students do not have cellphones to carry out online learning."

Another respondent (R3) said: "We carry out visits to students' homes with pleasure, because it is part of our duty. Only thing is that we are constrained by transportation and additional costs to pay for taxibike such so that we arrive at each student's house faster."

Few respondents also voicing the same concern: (R5) "Pity, because of this condition, teachers become more tired and spend a lot of money on student homes." There is a statement like this: (R4)" This is what deserves to be called a teacher, who should be honored and praised". There is also a respondent who said: "Parents feel appreciated because the teacher is willing to go to the student's house, even though the house is simple and the location is hard to reach" (R1).

There is also a different concern voiced by (R6) "students are bored at home because holidays are too long." (R2) said: "children are getting bored at home and want to go to school to play with their friends, but they are way more relaxed in learning activities without being impolite to the teacher."

Anothe respondent said: (R2) "parents take the hassle out of going to school if the child has not completed the assignment, because the parent brings the child's assignment to school." A respondent also voicing the same opinion: (R6) "Parents are tired because they come home from work (farm/sea), they have to check their children's lessons, because if they don't finish when the teacher comes to the next meeting, parents have to bring their child's assignments to school".

\section{b. Discussion}

A total of 6 respondents have provided statements and opinions which will be discussed as follows:

\section{a) Impact on students}

How much impact do students feel on the teaching and learning process at home is that students feel tired. Not all students can learn independently, because every child also has their own abilities. There are children who are indeed smart and responsive in facing a new lesson, but there are also children who have to be explained thoroughly about what they are going to learn. Every child if they have to be at home continuously without social interaction will eventualy feel bored, and that can affect a child's education. Because education can be received by a child if the child feels happy without any pressure or anything. Nevertheless, if he feels uninterested then the lessons will be difficult and it is challenging to comprehend what the student has learned.

In general, children's learning interest is influenced by two factors, namely internal and external factors. Internal factors that come from within the child including: physical factors (consisting of health factors and disabilities), psychological factors (consisting of intelligence, attention, interests, talents, motivation, perception, maturity and readiness) and fatigue. While external factors that come from outside the child include: factors from the family, namely the way parents educate, relationships between family members, home atmosphere, family economic conditions, parents' undertstanding, cultural background; school factors, namely teaching methods, curriculum, teacher-child relationships, childchild relationships, school discipline, learning media, school time, building conditions, 
learning methods and homework; factors from society, namely the activities of children in society, media, social friends, and forms of community life.

One of the external factors that influence children's interest in learning is the assignment of homework. According to Muijs, et al (2008: 150) "Homework can be defined as an activity outside the classroom which is an extension of class assignments." Homework is one aspect of teaching that is most widely used by teachers. On the other hand, children often perceive homework as a burden. Homework can be designed with the intention of increasing children's interest in learning, this is because with the provision of homework, the learning intensity of the child will increase and the level of mastery of the child's material increases with the need for the child to do the assignment that has been given by the teacher.

\section{b). Impact on teachers}

With a home visit, students can capture visual and audio learning, because not all of the students master one of these learning media. There must be both, such as teachers writing and students seeing firsthand. Home visit activities provide opportunities for teachers to find out the character of students. This can be realized if the cooperation between parents and teachers can be established. This effort is made by the teacher in order to create a pleasant atmosphere with both parents and students. The existence of good communication can avoid misunderstandings in the process of developing children's potential both at school and at home. The same direction between education in schools and education at home will create a harmonious atmosphere for students so that they are able to develop their potential better.

One thing that the researcher's realize is that when carrying out a home visit activity, it has an impact on high financial needs for transportation and physical fatigue, given the geographical conditions where students live in mountainous and coastal areas in the 4 different villages. Moreover, teachers mostly do not posses private means for transportation. Therefore, the teachers' dedication to continue teaching is nothing to be underestimated.

Solikhan (2015) argues that basically teachers always pay attention to others, be it students or parents. In conditions of heavy burdens, sometimes teacher can appear cheerful, all smiles, full of humor, tolerant, and empathetic. But sometimes those traits are not permanent, sometimes teachers are frustrated, lazy, sullen and easily offended. This however, made parents and students looked down upon a teacher. If teacher capable of hiding negative emotions and only showing the positive ones, the teaching will eventually be better. Teachers' cheerful attitude will benefit them because the lessons which run succesful will save teachers' energy.

Everyone, including teachers, prefers to talk with cheerful people, as well as students and parents who prefer to go along with teachers who are always cheerful and all smile. The teacher's smile is contagious, therefore smiling a lot at students and parents makes teacher's relationship with students and parents closer. Close relationships with students and parents are important for success as a teacher. The close relationship makes parents not hesitate to ask in depth about their child's condition and what can be done for the success of their child. Likewise teachers, they also do not hesitate to express their opinions as they are for the good or success of students.

\section{c). Impact for parents}

The obstacle faced by parents in learning with the Home Visit strategy carried out by the Kusu-Kusu Sereh Christian Middle School is that they have to be extra in controlling the tasks made by the child. If the assignment has not been completed during the next 
home visit as scheduled, the parents must bring the assignment to school because students are prohibited from going to school. This is a burden for parents.

Not all students can learn independently, because every child also has their own characteristics. There are children who are indeed smart and responsive in facing a new lesson, but there are also children who must first be explained about what they are going to learn. Every child if they have to be at home continuously without social interaction will feel uninterested, and that can affect a child's education. Because education can be received by a child if the child feels happy without any pressure.

Families, especially parents, are very influential on children's development so that children have emotional stability. The family is the first and foremost educational institution for children. Therefore family education will greatly determine the educational process in a person to undergo further education. As stated by Sudjana (2010) that family education appears in the world of education which is based on 2 phenomenas of community life, both circumstances and changes that occur in the surrounding environment also affect family life.

The notion of family from a psychological point of view is defined as a group of people who live together in a joint residence and each member feels an inner connection so that they influence each other, care for each other and give themselves up. Meanwhile, from a pedagogical point of view, the family is a communion of life in which affection between the couple of two types of humans is confirmed by marriage, which aims to perfect each other. So the family can be interpreted as a unit (group) where each member needs and is interdependent with one another and all members of the group have common interests and duties. Meanwhile, Soejono Sukanto (2006) argues that the family is the smallest unit in society that regulates proper sexual relations, or is referred to as a place for socialization, namely the process by which new community members get education to know, understand, obey, and respect the rules, as well as the prevailing values. In this case the family supports each other in achieving common goals, especially children born into the family.

A harmonious relationship between school and society is increasingly felt important in people who have realized and understood the importance of education for children. However, for people who do not realize the importance of a harmonious relationship, a cooperative relationship does not need to be fostered. In people who do not realize the importance of education, schools are required to be more effective and creative to create more harmonious cooperative relationships. The relationship between school and community cooperation can be classified into three types of relationships, namely (1) educational relationships, (2) cultural relationships, and (3) institutional relationships.

The existence of forms of cooperation between parents and teachers is part of an educational relationship in order to educate students so that students who have good academic abilities and behavior. This educational relationship aims to realize the same principles in educating children so that children do not experience confusion with different educational patterns at home and at school. Communication carried out by parents and teachers can be realized in various forms, including through text messages, telephone calls, face-to-face meetings in class, through parent-student meetings, and visits to students' homes. Some of these ways are done so that communication is maintained properly so that teachers and parents can find out about children's development and avoid misunderstandings.

Thus, the learning carried out by SMP Kristen Kusu-Kusu Sereh with the Home Visit strategy is a step that should be emulated by other schools that have the same problem with the condition of students during the Covid-19 pandemic. 


\section{Conclusion}

Based on the discussions, it can be concluded that:

a. The impact of the Covid-19 pandemic on students is that the learning process is carried out at home resulting in students feeling bored because they want to interact with other friends, but are more relaxed in learning activities without leaving politeness towards the teacher.

b. The impact of the Covid-19 pandemic on teachers is an increase in workload and financial needs because the Home Visit activity with the location of the four villages where students lived need a large amount of energy and funding.

c. The impact of the Covid-19 pandemic for parents is the extra attention that parents must take to control learning activities, especially the completion of children's tasks.

\section{References}

Anjani, D., Suyanto, I., Suripto, 2016. Penerapan Model Take and Give dengan Media Grafis Dalam Peningkatan Pembelajaran IPS Tentang Persiapan Kemerdekaan Indonesia Pada Siswa Kelas V SDN 1 Tambakagung Tahun Ajaran 2015/2016. Kalam Cendekia.

Bernard, H. R, 2002. Research methods in anthropology: Qualitative and quantitative approaches (3rd ed.). Walnut Creek, CA: Altamira Press.

Carlsson, M, G B Dahl, B Ockert and D Rooth, 2015. The Effect of Schooling on Cognitive Skills. Review of Economics and Statistics

Creswell, JW, 2013. Qualitative Inquiry \& Research Design: Choosing

M Padilla-Díaz -, 2015. Phenomenology in educational qualitative research: Philosophy as science or philosophical science. International Journal of Educational Excellence, anagmendez.net

Nana Sudjana, 2010. Dasar-dasar Proses Belajar, Sinar Baru Bandung

Soerjono Soekanto, 2006. Sosiologi Suatu Pengantar diterbitkan, Rajawali Pers.

Timothy C. Guetterman, 2015. Descriptions of Sampling Practices Within Five Approaches to Qualitative Research in Education and the Health Sciences. Forum Qualitative Sozialforschung

https://jatengprov.go.id/beritadaerah/home-visit-metode-alternatif-pembelajaran-di-masapandemi/ Accessed September 15, 2020

https://www.researchgate.net/publication/280775771_Descriptions_of_Sampling_Practic es_Within_Five_Approaches_to_Qualitative_Research_in_Education_and_the_He alth_Sciences Accessed September 15, 2020 